\title{
Exponential fertilization of Pinus monticola seedlings: nutrient uptake efficiency, leaching fractions, and early outplanting performance
}

\author{
R. Kasten Dumroese, Deborah S. Page-Dumroese, K. Francis Salifu, and \\ Douglass F. Jacobs
}

\begin{abstract}
We evaluated nutrient uptake efficiency and subsequent leaching fractions for western white pine (Pinus monticola Dougl. ex D. Don) seedlings grown with exponentially increasing or conventional (constant) fertilization in a greenhouse. Conventional fertilization was associated with higher leachate electrical conductivity and greater nutrient losses, which were more pronounced for the more mobile $\mathrm{NO}_{3}-\mathrm{N}$ than for $\mathrm{NH}_{4}-\mathrm{N}$. Exponential fertilization increased seedling nitrogen $(\mathrm{N})$ uptake efficiency $(75 \%)$, which helped reduce leaching losses compared to conventional fertilization $(50 \%)$. Although exponentially fertilized plants received $45 \%$ less fertilizer $\left(20 \mathrm{mg} \mathrm{N} \cdot \mathrm{plant}^{-1}\right)$ during the establishment and accelerated growth phases compared with conventional cohorts (36 mg N.plant ${ }^{-1}$ ), seedling morphological characteristics and nutrient status were similar at the end of greenhouse culture and after 2 years of growth in the field, except that exponential fertilization increased root volume after the first year and also increased ectomycorrhizal colonization. Reduction of applied fertilizer quantities and enhanced fertilizer uptake efficiency through exponential fertilization allows for production of high-quality seedlings while simultaneously minimizing fertilizer inputs and mitigating potential environmental contamination.
\end{abstract}

\begin{abstract}
Résumé : Les auteurs ont évalué l'efficacité du prélèvement des nutriments et les fractions subséquemment lessivées pour des semis de pin blanc de l'Ouest (Pinus monticola Dougl. ex D. Don) cultivés en serre et fertilisés de façon exponentielle ou conventionnelle (constante). La fertilisation conventionnelle a été associée à une plus grande conductivité électrique du lessivat et à des pertes en nutriments plus élevées, lesquelles étaient plus prononcées pour $\mathrm{N}-\mathrm{NO}_{3}$ mobile que pour $\mathrm{N}_{-} \mathrm{NH}_{4}$. La fertilisation exponentielle a accru l'efficacité du prélèvement de $\mathrm{N}$ par les semis (75\%), ce qui a aidé à réduire les pertes par lessivage comparativement à la fertilisation conventionnelle (50\%). Bien que les plants fertilisés de façon exponentielle aient reçu $45 \%$ moins de fertilisant $\left(20 \mathrm{mg} \mathrm{N} \cdot \mathrm{semis}^{-1}\right)$ durant les phases d'établissement et de croissance accélérée comparativement aux cohortes conventionnelles (36 mg N·semis $\left.{ }^{-1}\right)$, les caractéristiques morphologiques et le statut nutritionnel des semis étaient similaires à la fin de la période de culture en serre et après 2 ans de croissance au champ, sauf que la fertilisation exponentielle a augmenté le volume de racines après la première année ainsi que la colonisation ectomycorhizienne. La réduction des quantités de fertilisants utilisées et l'augmentation de l'efficacité du prélèvement des nutriments obtenues avec la fertilisation exponentielle permettent un production de semis de haute qualité tout en minimisant les apports de nutriments et en atténuant le potentiel de contamination environnementale.
\end{abstract}

[Traduit par la Rédaction]

\section{Introduction}

Providing proper mineral nutrition to seedlings in nurseries is essential for optimum performance after outplanting (Bigg and Schalau 1990). Fertilization during nursery culture has ramifications for seedling morphological and physiological characteristics (Landis 1985; Rook 1991) and environmental quality (Molitor 1990; Brown 1992). Potential risks for serious nutrient leaching exist in container production systems because large volumes of irrigation water are used and nearly all fertilizer is applied as fertigation (Dumroese et al. 1995). For example, about $49 \%-72 \%$ of the irrigation and $32 \%-$ $60 \%$ of supplied nitrogen $(\mathrm{N})$ were discharged from container nursery production systems (Dumroese et al. 1992, 1995). Additionally, Juntunen et al. (2003) noted 60\%-80\% of applied $\mathrm{N}$ was lost from one Finnish nursery production system, while only about $15 \%-63 \%$ of applied fertilizer was recovered in seedlings in another study (Juntunen et al. 2002).

Increased nutrient losses resulted in heavy nitrate $\left(\mathrm{NO}_{3}\right)$ loads greater than $2000 \mathrm{~kg} \mathrm{~N} \cdot \mathrm{ha}^{-1}$ in the top $1 \mathrm{~m}$ of soil below

Received 26 May 2005 Accepted 26 September 2005. Published on the NRC Research Press Web site at http://cjfr.nrc.ca on 21 December 2005.

R.K. Dumroese. ${ }^{1}$ USDA Forest Service, Southern Research Station, 1221 South Main Street, Moscow, ID 83843, USA.

D.S. Page-Dumroese. USDA Forest Service, Rocky Mountain Research Station, 1221 South Main Street, Moscow, ID 83843, USA.

K.F. Salifu and D.F. Jacobs. Hardwood Tree Improvement and Regeneration Center, Department of Forestry and Natural Resources, Purdue University, West Lafayette, IN 47907, USA.

${ }^{1}$ Corresponding author (e-mail: kdumroese@fs.fed.us). 
commercial production greenhouses (Molitor 1990). Such increases could have detrimental environmental effects to humans through impact on drinking water supplies (Brown 1992). $\mathrm{NO}_{3}$ levels greater than $50 \mathrm{mg} \cdot \mathrm{L}^{-1}\left(11.3 \mathrm{mg} \mathrm{NO}-\mathrm{N} \cdot \mathrm{L}^{-1}\right)$ in public drinking water supplies are considered unsafe for human consumption (World Health Organization 2004).

Groundwater pollution and eutrophication of surface water are well documented for agricultural practices (Newbould 1989). Excepting studies by Dumroese et al. (1992, 1995) and Juntunen et al. (2002, 2003), little information is available regarding the potential risk of groundwater pollution due to nutrient leaching losses from container production of forest tree seedlings (Landis et al. 1992). Unless $\mathrm{NO}_{3}$ discharge levels are moderated to prevent increased contamination of drinking and (or) stream water, growing evidence suggests that political action may be taken to control the use of $\mathrm{N}$ fertilizers (Thompson 1985; Newbould 1989) or to regulate discharge from commercial nursery production systems (Johnson 1992). Such regulation is currently implemented in Oregon, USA (Grey 1991). Thus, a better understanding of methods to improve fertilizer use efficiency and correspondingly reduce $\mathrm{N}$ discharge from nurseries is warranted (Juntunen and Rikala 2001; Juntunen et al. 2002, 2003; Dumroese 2003).

Synchronizing fertilizer supply with crop demand (Ingestad and Lund 1986; Timmer 1997; Dumroese 2003) may enhance nutrient uptake and fertilizer use efficiency by forest tree seedlings. This synchronization, achieved through use of exponential fertilization, has been examined in a variety of forest tree species (McAlister and Timmer 1998; Qu et al. 2003; Salifu and Timmer 2003a; Close et al. 2005; Hawkins et al. 2005), with the intent of loading seedlings with high $\mathrm{N}$ levels by applying fertilizer at rates similar to or greater than that provided through conventional fertilization. There is a need, however, to examine the potential to produce seedlings of similar quality with lower quantities of $\mathrm{N}$ applied exponentially (Hawkins et al. 2005), thereby allowing nurseries to apply nutrients more efficiently and with less cost. Additionally, past research has yet to quantify potential decreases in nursery $\mathrm{N}$ leaching losses through use of exponential versus conventional fertilization.

We evaluated conventional fertilization (36 mg N.plant ${ }^{-1}$ ) compared with reduced nutrient application via exponential fertilization (45\% less fertilizer: $20 \mathrm{mg} \mathrm{N} \cdot$ plant $^{-1}$ ) for a crop of western white pine (Pinus monticola Dougl. ex D. Don), an important species of the Pacific Northwest, USA, and British Columbia, Canada. We tested the hypotheses that $(i)$ exponential fertilization will increase seedling nutrient uptake efficiency and reduce leaching losses, (ii) higher electrical conductivity in leachate associated with conventional fertilizer addition schedules will result in greater nutrient leaching losses, and (iii) morphological quality and field performance of seedlings grown with less $\mathrm{N}$ addition applied exponentially will be similar to that of conventional cohorts.

\section{Materials and methods}

\section{Greenhouse study}

\section{Growth conditions and fertility treatments}

Western white pine seeds (Moscow Arboretum seed source) were sown into Ray Leach ${ }^{\mathrm{TM}}$ pine cells (Stuewe \& Sons,
Inc., Corvallis, Oregon, USA) filled with a 1:1 mix of sphagnum peat-moss : vermiculite medium. Each container held 200 cells, and each cell measured $2.5 \mathrm{~cm} \times 16 \mathrm{~cm}$ $(66 \mathrm{cc})$. Filled containers were placed onto six rolling tables in the center of a greenhouse at the University of Idaho Forest Research Nursery near Moscow, Idaho, USA $\left(41^{\circ} 43^{\prime} 33^{\prime \prime} \mathrm{N}, 117^{\circ} 00^{\prime} 37^{\prime \prime} \mathrm{W}\right)$. Each table held 48 containers. Germinated seedlings (97\% occupancy success) were irrigated with a traveling spray system, where each pass over a table delivered $16 \mathrm{~L}\left(1.8 \mathrm{~L} \cdot \mathrm{m}^{-2}\right)$ uniformly to cultured plants. Irrigation efficiency with this container type and traveling boom system was $60 \%$ (R.K. Dumroese, unpublished data). Fertilizer treatments began 2 weeks after sowing (9 April, Julian day 100) and continued for 13 weeks (through day 187). Conventional (control) or exponential fertilization treatments were assigned at random to the six tables, which comprised three replications of each treatment. In addition to the fertilization treatments, all seedlings received phosphoric acid at $41 \mathrm{mg} \mathrm{P} \cdot \mathrm{L}^{-1}$ to lower irrigation water $\mathrm{pH}, \mathrm{MgSO}_{4}$ at $24 \mathrm{mg} \mathrm{S} \cdot \mathrm{L}^{-1}$, and Solubar at $0.5 \mathrm{mg}$ boron $(\mathrm{B}) \cdot \mathrm{L}^{-1}$ to meet known needs of seedlings produced at this facility (Wenny and Dumroese 1994).

The conventional fertilization treatment was typical for western white pine seedlings grown at this facility (Wenny and Dumroese 1994). During the establishment phase, seedlings received six applications (twice per week for 3 weeks) of Peters Professional ${ }^{\circledR}$ Conifer Starter ${ }^{\mathrm{TM}}\left(7 \mathrm{~N}: 40 \mathrm{P}_{2} \mathrm{O}_{5}: 17 \mathrm{~K}_{2} \mathrm{O}\right)$ at $42 \mathrm{mg} \mathrm{N} \cdot \mathrm{L}^{-1}$. Seedlings received 10 applications (once per week for 10 weeks) of Peters Professional ${ }^{\circledR}$ Conifer Grower ${ }^{\mathrm{TM}}$ (20N:7P $\mathrm{O}_{5}: 19 \mathrm{~K}_{2} \mathrm{O} ; 7.1 \% \mathrm{NH}_{4}-\mathrm{N}, 11.6 \% \mathrm{NO}_{3}-\mathrm{N}$ ) at $192 \mathrm{mg}$ $\mathrm{N} \cdot \mathrm{L}^{-1}$ alternated with 10 applications (once per week for 10 week) of liquid ammonium calcium nitrate (CAN-17; $\left.17 \% \mathrm{~N} ; 5.6 \% \mathrm{NH}_{4}-\mathrm{N}, 11.2 \% \mathrm{NO}_{3}-\mathrm{N}\right)$ at $170 \mathrm{mg} \mathrm{N} \cdot \mathrm{L}^{-1}$ during the accelerated growth phase. During the establishment and accelerated phases, each seedling received $36 \mathrm{mg} \mathrm{N}$ total. The total irrigation amount for each fertigation was determined gravimetrically according to White and Marstalerz (1966). Conventional seedlings received one cycle (two passes, forward and return) with the traveling boom of plain water, enough cycles with fertilizer solution to bring the block mass back to container capacity, and a final cycle of plain water to rinse the foliage.

Exponential fertilization delivered nutrients at exponentially increasing addition rates (Ingestad and Lund 1986; Timmer and Aidelbaum 1996) according to eq. 1:

$$
\text { [1] } \quad N_{\mathrm{T}}=N_{\mathrm{S}}\left(\mathrm{e}^{r t}-1\right)
$$

where $r$ is the relative addition rate required to increase $N_{\mathrm{S}}$ (initial $\mathrm{N}$ content in plant) to a final $\mathrm{N}$ content $\left(N_{\mathrm{T}}+N_{\mathrm{S}}\right)$, and $N_{\mathrm{T}}$ was the desired amount to be added over the number of fertilizer applications $(t) . N_{\mathrm{S}}$ was determined from three replicates of 300 germinants randomly collected across all six tables, which were oven-dried $\left(48 \mathrm{~h}\right.$ at $\left.60{ }^{\circ} \mathrm{C}\right)$ and ground to pass a $0.04-\mathrm{mm}$ mesh. Subsequently, total $\mathrm{N}$ was analyzed with a LECO-600 CHN analyzer (LECO Corp., St. Joseph, Michigan, USA). $N_{\mathrm{S}}$ was calculated to be $1.05 \mathrm{mg} \mathrm{N} \cdot$ plant $^{-1}$. Historic crop data indicated that $N_{\mathrm{T}}$ at the time of bud initiation for a typical crop was $20 \mathrm{mg}$ N (R.K. Dumroese, unpublished data). At this facility, western white pine requires 13 weeks of growing time to achieve target morphological 
characteristics before buds are initiated. Typically, the crop is fertigated twice each week, therefore $t=26$. Using eq. 1 , the relative addition rate $(r)$ was calculated to be 0.115 . The quantity of fertilizer to apply on a specific day $\left(N_{t}\right)$ was computed using eq. 2 :

$$
N_{t}=N_{\mathrm{S}}\left(\mathrm{e}^{r t}-1\right)-N_{t-1}
$$

where $N_{t-1}$ is the cumulative amount of $\mathrm{N}$ added up to and including the previous application. Peters Professional ${ }^{\circledR}$ Conifer Starter ${ }^{\mathrm{TM}}$ was used for the first six applications (twice per week for 3 weeks) followed by Peters Professional ${ }^{\circledR}$ Conifer Grower ${ }^{\mathrm{TM}}$ for the remaining 20 applications (twice per week for 10 weeks). Once container capacity was determined, exponentially treated seedlings received the first $25 \%$ of that volume as plain water, followed by $65 \%$ of the volume as fertigation solution, with the remaining $10 \%$ used to rinse the foliage. During exponential fertilization, each seedling received $20 \mathrm{mg} \mathrm{N}$ total. From conclusion of the accelerated growth phase until harvest (the hardening phase), seedlings in both treatments received Peters Professional ${ }^{\circledR}$ Conifer Finisher ${ }^{\mathrm{TM}}\left(5 \mathrm{~N}: 25 \mathrm{P}_{2} \mathrm{O}_{5}: 35 \mathrm{~K}_{2} \mathrm{O}\right)$ at $24 \mathrm{mg} \mathrm{N} \cdot \mathrm{L}^{-1}$ alternated with CAN-17 at $161 \mathrm{mg} \mathrm{N} \cdot \mathrm{L}^{-1}$, and the total irrigation amount for each fertigation was determined gravimetrically according to White and Marstalerz (1966).

\section{Sampling and chemical analysis of data}

Eight times, about every 24 days after the first fertilization (9 April (day 100) through 2 August (day 215)) and again at day 288 (16 October), 30 seedlings were randomly selected from each treatment replication and measured for shoot height (medium to top of stem or bud when present), root-collar diameter ( $1 \mathrm{~cm}$ above medium), and biomass (after drying to constant mass at $60{ }^{\circ} \mathrm{C}$ ).

Each fertigation applied from 9 April (day 100) through 2 August (day 215) was measured at three sources: (i) traveling boom, (ii) leachate from containers, and (iii) errant spray (discharge) that included leachate and fertigation which dripped or sprayed through holes in the containers as well as water sprayed directly in aisles. Errant spray was used to quantify total fertilizer solution discharged from this nursery production facility. Boom solution and leachate were collected in a similar manner. For each fertigation, a $15 \mathrm{~cm}$ length of plastic tubing was attached to the bottom of randomly selected individual cells. A plastic collection bottle was fitted at the opposite end, and a hole $2 \mathrm{~mm}$ in diameter was drilled into the tube to prevent suction from forming as water percolated downward in the medium. For boom spray, 5 empty cells per treatment replication (15 cells total) were sampled, whereas 3 cells per treatment replication containing seedlings were sampled for leachate. The volume of solution was measured to the nearest $0.1 \mathrm{~mL}$ about $30 \mathrm{~min}$ after irrigation ceased and then frozen until analyzed for $\mathrm{N}$ and electrical conductivity (EC). Errant spray was quantified by hanging a $15 \mathrm{~cm}$ wide $\times 6 \mathrm{~m}$ long piece of plastic gutter beneath each table, positioned diagonally to intercept irrigation water being applied beyond the boundary of the tables as well as water dripping through the containers. Gutters drained into plastic containers. About $30 \mathrm{~min}$ after irrigation ceased, total volume was measured to the nearest $10 \mathrm{~mL}$, and subsamples from each container were then frozen until $\mathrm{N}$ and EC analy- sis. EC was determined using an Accumet Model 20 (Fisher Scientific International, Hampton, New Hampshire, USA). Seedling nutrient $(\mathrm{B}$, calcium $(\mathrm{Ca})$, copper $(\mathrm{Cu})$, iron $(\mathrm{Fe})$, potassium $(\mathrm{K})$, magnesium $(\mathrm{Mg})$, manganese $(\mathrm{Mn})$, molybdenum (Mo), N, phosphorus (P), and zinc ( $\mathrm{Zn})$ ) concentration for each sample date was determined by Scotts Testing Laboratory (Allentown, Pennsylvania, USA) using a Carlo Erba CHN analyzer (Thermo Electron Corporation, Milan, Italy) for $\mathrm{N}$ concentrations and acid digestion and an ICP Spectrometer for the other elements. Nutrient efficiency was calculated by dividing the nutrient content in seedlings by the total amount of nutrients applied to the seedlings. N concentration in water samples was accomplished with a LECO$600 \mathrm{CHN}$ analyzer. Seedlings for the field study were harvested in mid November and placed upright into polybaglined waxed cardboard boxes and held in cold storage at $1-$ $2{ }^{\circ} \mathrm{C}$ until outplanted.

\section{Field study}

In April, 120 seedlings from each treatment (three replicates of 40 seedlings) were dibble planted at $1 \mathrm{~m} \times 1 \mathrm{~m}$ spacing at the USDA Forest Service, Priest River Experimental Forest in northern Idaho, USA $\left(48^{\circ} 11^{\prime} 10^{\prime \prime} \mathrm{N}, 116^{\circ} 54^{\prime} 35^{\prime \prime} \mathrm{W}\right)$. Formerly forested with mixed conifers, the area was cleared, fenced to exclude rodents and mammals, and used as a nursery site for decades. The soil was rototilled to a depth of $30 \mathrm{~cm}$ the fall before outplanting. The soil is a coarse, loamy, mixed frigid Andic Xerochrept (Soil Survey Staff 1996) similar to a Brunisol but having a volcanic ash-modified surface layer. Mean annual precipitation and temperature were $84 \mathrm{~cm}$ and $6.6{ }^{\circ} \mathrm{C}$, respectively. About $80 \%$ of the precipitation falls as snow. Very few weeds appeared, and these were periodically removed by hand. During November of the first and second year, 10 seedlings from each treatment replication (block) were excavated and root systems gently washed. Seedling survival, shoot height (ground line to tip of terminal bud), root-collar diameter, rooting depth, and root volume (Burdett 1979) were measured. Active ectomycorrhizal root tips were plump, whitish, and turgid and counted following the definition and technique of Harvey et al. (1980). Plants were then partitioned to shoots and roots and dried at $60{ }^{\circ} \mathrm{C}$ until constant mass for dry mass determination.

\section{Experimental design and statistical analysis}

The greenhouse experiment examined effects of two fertilization treatments (exponential vs. conventional) on western white pine seedling growth and nutrition using three replications. Subsequently, conventional and exponentially grown seedlings were outplanted in three replicate blocks in the field to examine influence of prior nursery culture on outplanting performance. Analysis of variance was conducted on all data using SAS (SAS Institute Inc. 2001). Analysis of variance (ANOVA) treatment effects for greenhouse data were considered statistically significant at $P=0.05$ and when treatment effects were significant, means were ranked according to Tukey's honestly significant difference test $(\alpha=0.05)$. To minimize the possibility of making a type II error associated with the reduced number of sampling units (i.e., 10 vs. 30 seedlings per treatment replication) for outplanting data, ANOVA treatment effects were considered significant for 
Fig. 1. Electrical conductivity (A), leached amounts of $\mathrm{NO}_{3}-\mathrm{N}$ (B), and leached amounts of $\mathrm{NH}_{4}-\mathrm{N}$ (C) from western white pine container production systems under conventional or exponential fertilization schedules for 87 days in a greenhouse environment. Broken line represents termination of fertilizer treatments for hardening purposes.

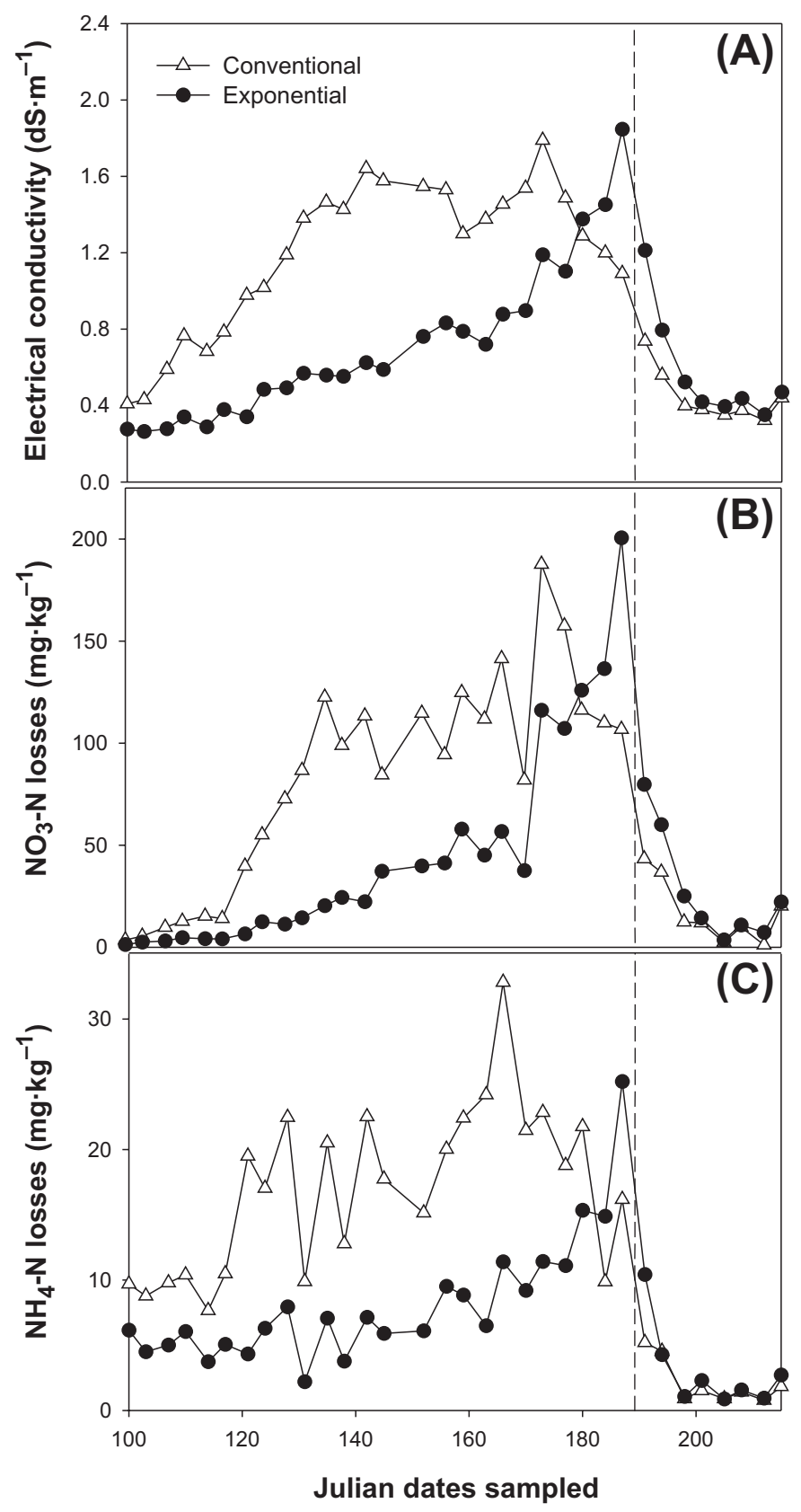

these variables at $P=0.10$, and where significant, treatment means were ranked according to Tukey's honestly significant difference test $(\alpha=0.10)$.

\section{Results and discussion}

\section{Nutrient leaching and uptake}

Generally, electrical conductivity (EC) of the leachate increased from initiation of fertilizer application (day 100) to day 187 , then declined thereafter because of changes in nurs-
Fig. 2. Total water discharged (errant spray) during each fertigation event from western white pine container production system under conventional or exponential fertilization schedules for 87 days in a greenhouse environment.

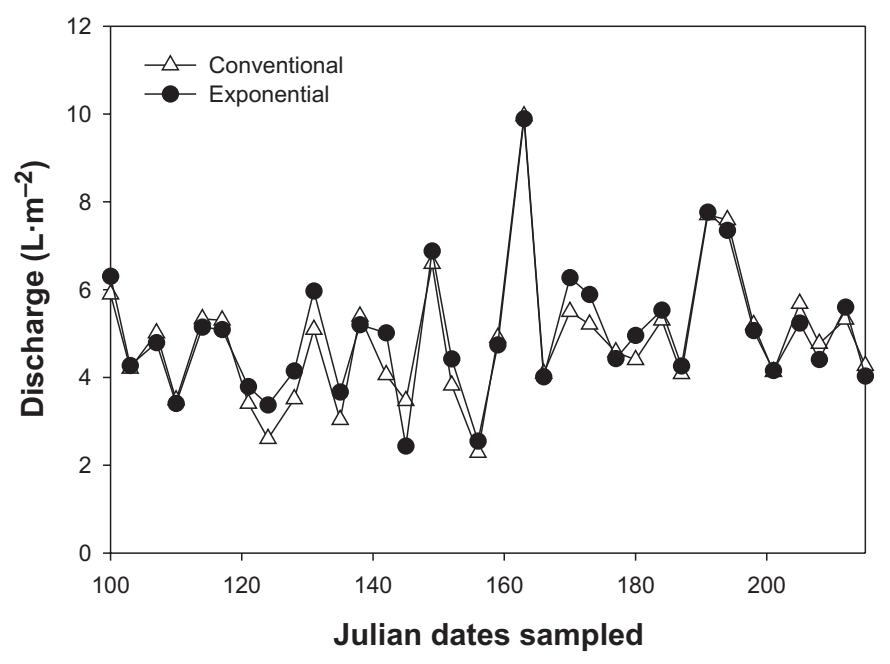

ery cultural practices to harden seedlings for overwinter storage (Fig. 1A). Higher EC associated with conventional versus exponential fertilization schedules reflects greater fertility in the former treatment, which resulted in more nutrient losses (Figs. 1A, 1B, and 1C). The EC range found in this study $\left(0.30-1.90 \mathrm{dS} \cdot \mathrm{m}^{-1}\right)$ is within the range of substrate EC recommended for optimum growth of conifer container stock (Phillion and Bunting 1983; Timmer and Parton 1984; Jacobs et al. 2003).

Leachate for pine crops averaged $2.4 \mathrm{~mL} \cdot \mathrm{m}^{-2} \cdot$ day $^{-1}$ in a Finnish nursery, where regular leaching of the medium is not practiced (Juntunen et al. 2002), compared with $1.3 \mathrm{~L} \cdot \mathrm{m}^{-2} \cdot \mathrm{day}^{-1}$ in our study, where leaching was implemented and seedlings were grown almost twice as dense. Greater volumes of water discharge can often explain higher leaching losses (McAvoy et al. 1992); however, $\mathrm{N}$ loss through leaching was about $12 \mathrm{mg} \mathrm{N} \cdot \mathrm{m}^{-2} \cdot \mathrm{day}^{-1}$ for pines in Finland (Juntunen et al. 2002) compared with 8 and $4 \mathrm{mg} \mathrm{N} \cdot \mathrm{m}^{-2} \cdot \mathrm{day}^{-1}$ for conventional and exponentially fertilized seedlings, respectively, in this study. More than $50 \%$ of the leachate in the Finnish study was associated with precipitation events after the crop was moved outside (Juntunen et al. 2002), which probably contributed to the higher $\mathrm{N}$ losses. Conventional fertilization also showed greater losses of the more mobile $\mathrm{NO}_{3}-\mathrm{N}$ than of $\mathrm{NH}_{4}-\mathrm{N}$ (Figs. 1B and 1C), as was similarly noted by Juntunen et al. (2002). Because the amount of discharged water was similar for both treatments (Fig. 2), increased fertilizer addition may explain the greater $\mathrm{N}$ leaching losses in the conventional treatment in our study. Irrigation to container capacity (White and Marstalerz 1966) and synchronizing application with crop demand could increase uptake efficiency and act to minimize leaching losses (Ingestad and Lund 1986; Dumroese et al. 1995; Salifu and Timmer 2003a).

Nutrient uptake efficiency was higher $(P<0.05)$ in exponentially than conventionally cultured seedlings (Fig. 3), suggesting better synchronization of supply with plant demand in the former treatment. $\mathrm{N}$ uptake efficiency was $75 \%$ in exponentially grown seedlings compared with $50 \%$ in conven- 
Fig. 3. Nutrient uptake efficiency (percentage of applied) in western white pine seedlings grown conventionally or exponentially for 87 days in a greenhouse environment. Bars marked with similar letters are not statistically different according to Tukey's honestly significant difference test at $\alpha=0.05$. Bars represent standard error of the mean. $\mathrm{N}$, nitrogen; $\mathrm{P}$, phosphorus; $\mathrm{K}$, potassium.

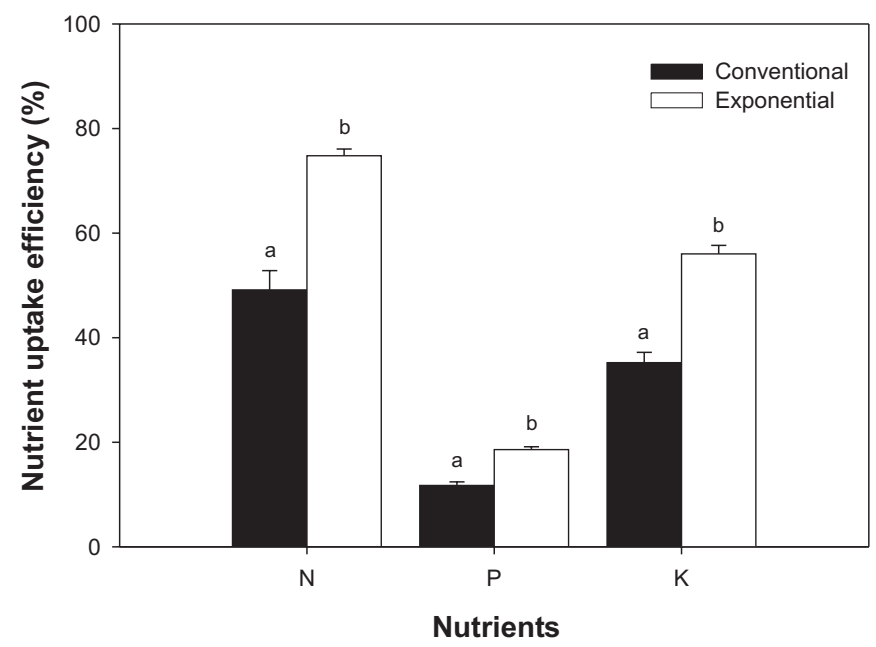

tionally grown plants (Fig. 3). Similar comparisons for $\mathrm{P}$ and $\mathrm{K}$ were $19 \%$ versus $12 \%$ and $56 \%$ versus $35 \%$, respectively, in exponentially and conventionally grown seedlings. Between $49 \%$ and $75 \%$ of applied fertilizer was recovered in seedlings in our study, similar to the $62 \%$ noted for pine by Juntunen et al. (2002). The unaccounted budget (25\%-51\%) may be explained by losses through volatilization or immobilization in the peat substrate (Timmer and Parton 1984; Juntunen et al. 2003). Nutrient concentration and content for the 11 nutrients were similar in both treatments after the accelerated growth phase and at the end of the growing season.

\section{Seedling growth}

Although exponentially grown plants received $45 \%$ less fertilizer compared with their conventional cohorts, morphological characteristics, as well as $\mathrm{N}$ concentration and content, were similar at the end of greenhouse culture (Table 1). Seedlings exceeded the minimum quality standards for this species in this container: height $>7.5 \mathrm{~cm}$, root-collar diameter $>2.3 \mathrm{~mm}$, and foliar $\mathrm{N}>2.0 \%$. Similar seedling morphology and $\mathrm{N}$ values between treatments in this study are consistent with results of other studies demonstrating similarity in plant quality between conventionally grown and exponentially fertilized seedlings at the end of nursery culture (Timmer 1997; Juntunen et al. 2003; Qu et al. 2003; Close et al. 2005). Further, after 2 years in the field, morphological and nutritional attributes of exponentially fertilized plants met outplanting expectations, as demonstrated by their similarity in performance with conventional cohorts (Table 1). After outplanting, more than $98 \%$ of seedlings in each treatment survived. In our study, exponentially fertilized seedlings were not nutrient loaded and had a similar $\mathrm{N}$ concentration to that of conventional cohorts. Therefore, the demonstrated improved outplanting field growth and nutrition of exponentially nutrient loaded plants noted in other studies (e.g., Salifu and Timmer 2003b; Close et al. 2005) was not observed, excepting greater root volume the first year after planting (Table 1).

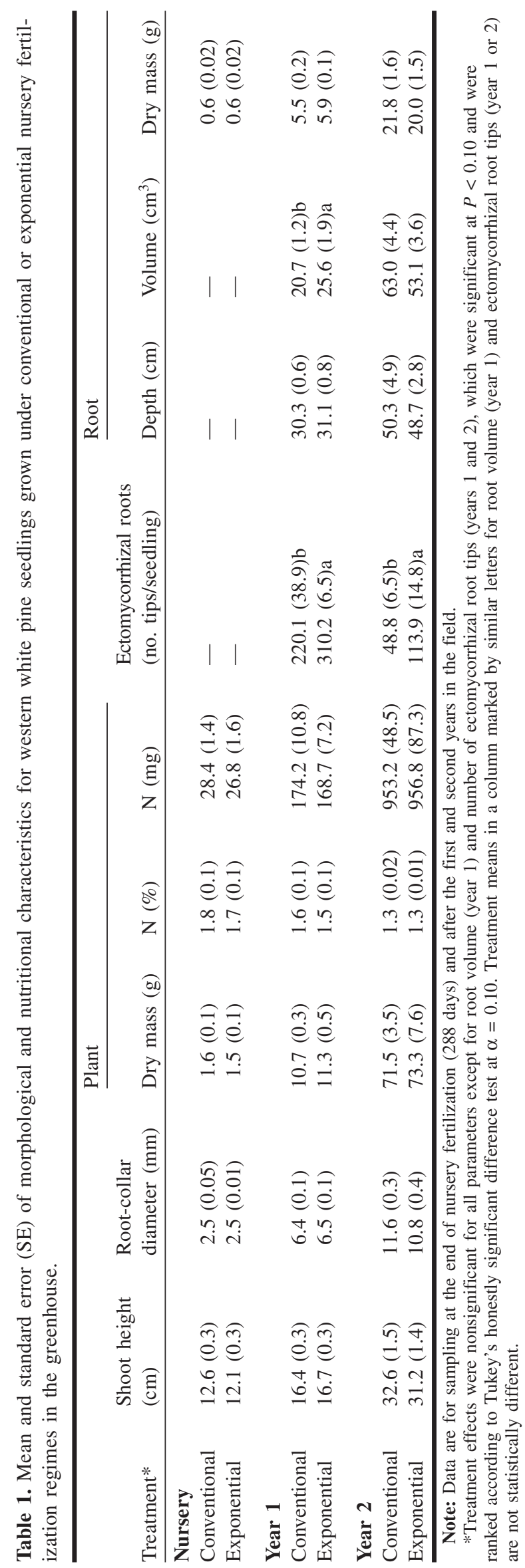

(C) 2005 NRC Canada 
Exponential fertilization significantly increased ectomycorrhizal colonization of root systems of outplanted western white pine by $41 \%$ and $233 \%$ in years 1 and 2, respectively (Table 1), similar to results of Quoreshi and Timmer (1998, 2000). Postplanting infection levels of ectomycorrhiza on seedling root systems are critical factors that can determine seedling survival and performance under field conditions (Trofymow and van den Driessche 1991). Increased acquisition of growth resources by ectomycorrhizal fungi can aid seedlings in overcoming moisture and nutrient stress, which can decrease transplant stress (Marx 1991), especially on poor or disturbed sites (Perry et al. 1987; Page-Dumroese et al. 1998).

Results demonstrate that applying nutrients at exponentially increasing rates to match plant demand in lieu of conventional fertilization may improve nutrient uptake efficiency in seedlings and thereby reduce quantities of nutrients discharged in forest tree nursery production systems. Enhanced nutrient use efficiency by exponentially fertilized seedlings allows for production of seedlings of similar quality and outplanting performance potential using substantially less $\mathrm{N}$ inputs. By reducing total fertilizer applied through exponential fertilization, seedling crops may be more efficiently and economically produced, while mitigating potential environmental contamination.

\section{Acknowledgments}

Dr. David L. Wenny graciously allocated greenhouse space, supplies, and funding to facilitate this work; Denny Dawes, Susan J. Morrison, and Kenneth E. Quick assisted with fertilizer applications and data collection. We appreciate the thorough reviews by the anonymous referees.

\section{References}

Bigg, W.L., and Schalau, J.W. 1990. Mineral nutrition and the target seedling. In Proceedings of the Combined Meeting of the Western Forest Nursery Associations, Roseburg, Ore., 13-17 August 1990. Edited by R. Rose, S.J. Campbell, and T.D. Landis. USDA For. Serv. Gen Tech. Rep. RM-200. pp. 139-160.

Brown, R.L. 1992. Results of the national survey of pesticides in drinking water wells. In Proceedings, Intermountain Forest Nursery Association, Park City, Utah, 12-16 August 1991. Technical coordinator T.D. Landis. USDA For. Serv. Gen. Tech. Rep. RM211. pp. 16-17.

Burdett, A.N. 1979. A nondestructive method for measuring the volume of intact plant parts. Can. J. For. Res. 9: 120-122.

Close, D.C., Bail, I., Hunter, S., and Beadle, C.L. 2005. Effects of exponential nutrient-loading on morphological and nitrogen characteristics and on after-planting performance of Eucalyptus globulus seedlings. For. Ecol. Manage. 205: 397-403.

Dumroese, R.K. 2003. Growth of Juniperus and Potentilla using liquid exponential and controlled-release fertilizers. Hortscience, 38: $1378-1380$.

Dumroese, R.K., Page-Dumroese, D.S., and Wenny, D.L. 1992. Managing pesticides and fertilizer leaching and runoff in a container nursery. In Proceedings, Intermountain Forest Nursery Association, Park City, Utah, 12-16 August 1991. Technical coordinator T.D. Landis. USDA For. Serv. Gen. Tech. Rep. RM211. pp. 27-33.
Dumroese, R.K., Wenny, D.L., and Page-Dumroese, D.S. 1995. Nursery waste water. The problem and possible remedies. In National Proceedings, Forest and Conservation Nursery Association. Technical coordinators T.D. Landis and B. Cregg. USDA For. Serv. Gen. Tech. Rep. PNW-GTR-365. pp. 89-97.

Grey, D. 1991. Eliminate irrigation runoff. Oregon's new plan. The Digger (March). No. 26. Oregon Association of Nurseries, Portland, Ore. pp. 21-23.

Harvey, A.E., Jurgensen, J.F., and Larsen, M.J. 1980. Clearcut harvesting and ectomycorrhizae: survival of activity on residual roots and influence on a bordering forest stand in western Montana. Can. J. For. Res. 10: 300-303.

Hawkins, B.J., Burgess, D., and Mitchell, A.K. 2005. Growth and nutrient dynamics of western hemlock with conventional or exponential greenhouse fertilization and planting in different fertility conditions. Can. J. For. Res. 35: 1002-1016.

Ingestad, T., and Lund, A.B. 1986. Theory and techniques for steady state mineral nutrition and growth of plants. Scand. J. For. Res. 1: 439-453.

Jacobs, D.F., Rose, R., and Haase, D.L. 2003. Development of Douglas-fir seedling root architecture in response to localized nutrient supply. Can. J. For. Res. 33: 118-125

Johnson, J.R. 1992. Nutrient runoff from nurseries-is it a problem? Int. Plant Propag. Soc. Comb. Proc. 41: 428-431.

Juntunen, M.-L., and Rikala, R. 2001. Fertilization practices in Finnish forest nurseries from the standpoint of environmental impact. New For. 21: 141-158.

Juntunen, M.-L., Hammar, T., and Rikala, R. 2002. Leaching of nitrogen and phosphorus during production of forest seedlings in containers. J. Environ. Qual. 31: 1868-1874.

Juntunen, M.-L., Hammar, T., and Rikala, R. 2003. Nitrogen and phosphorus leaching and uptake by container birch seedlings (Betula pendula Roth) growth in three different fertilizations. New For. 25: 133-147.

Landis, T.D. 1985. Mineral nutrition as an index of seedling quality. In Evaluating seedling quality: principles, procedures, and predictive abilities of major tests. Edited by M.L. Duryea. Forest Research Laboratory, Oregon State University, Corvallis, Ore. pp. 29 48.

Landis, T.D., Campbell, S., and Zenzen, F. 1992. Agricultual pollution of surface water and groundwater in forest nurseries. In Proceedings, Intermountain Forest Nursery Association, Bismarck, N.D., 14-18 August 1989. Technical coordinator T.D. Landis. USDA For. Serv. Gen. Tech. Rep. RM-211. pp. 1-15.

Marx, D.H. 1991. The practical significance of ectomycorrhizae in forest establishment. In Proceedings of the Marcus Wallenberg Foundation Symposium on Ecology of Mycorrhizae of Forest Trees, Stockholm, Sweden, 27 September 1991. Edited by B. Hägglund. The Marcus Wallenberg Foundation, Stockholm, Sweden. pp. 54-90.

McAlister, J.A., and Timmer, V.R. 1998. Nutrient enrichment of white spruce seedlings during nursery culture and initial plantation establishment. Tree Physiol. 18: 195-202.

McAvoy, J.J., Brand, H.M., Corbett, E.G., Bartok, J.W., Jr., and Botacchi, A. 1992. Effect of leachate fraction on nitrate loading to the soil profile underlying a greenhouse crop. J. Environ. Hort. 10: 167-171.

Molitor, H. 1990. The European perspective with emphasis on subirrigation and recirculation of water and nutrients. Acta Hort. 272: $165-173$.

Newbould, P. 1989. The use of nitrogen fertilizer in agriculture: Where do we go practically and ecologically? Plant Soil, 115: 297-311. 
Page-Dumroese, D.S., Harvey, A.E., Jurgensen, M.F., and Amaranthus, M.P. 1998. Impacts of soil compaction and tree stump removal on soil properties and outplanted seedlings in northern Idaho, USA. Can. J. Soil Sci. 78: 29-34.

Perry, D.A., Molina, R., and Amaranthus, M.P. 1987. Mycorrhizae, mycorrhizospheres, and reforestation: current knowledge and research needs. Can. J. For. Res. 17: 929-940.

Phillion, B.J., and Bunting, W.R. 1983. Growth of spruce seedlings at various soluble fertilizer salt levels. Tree Plant. Notes, 34: 31-33.

Qu, L.Y., Quoreshi, A.M., and Koike, T. 2003. Root growth characteristics, biomass and nutrient dynamics of seedlings of two larch species raised under different fertilization regimes. Plant Soil, 255: 293-302.

Quoreshi, A.M., and Timmer, V.R. 1998. Exponential fertilization increases nutrient uptake and ectomycorrhizal development of black spruce seedlings. Can. J. For. Res. 28: 674-682.

Quoreshi, A.M., and Timmer, V.R. 2000. Early outplanting performance of nutrient-loaded containerized black spruce seedlings inoculated with Laccaria bicolor: a bioassay study. Can. J. For. Res. 30: 744-752.

Rook, D.A. 1991. Seedling development and physiology in relation to mineral nutrition. In Mineral nutrition of conifer seedlings. Edited by R. van den Driessche. CRC Press LLC, Boca Raton, Fla. pp. 85-111.

Salifu, K.F., and Timmer, V.R. 2003a. Optimizing nitrogen loading in Picea mariana seedlings during nursery culture. Can. J. For. Res. 33: 1187-1294.

Salifu, K.F., and Timmer, V.R. 2003b. Nitrogen retranslocation response of young Picea mariana to nitrogen-15 supply. Soil Sci. Soc. Am. J. 67: 309-317.

SAS Institute Inc. 2001. SAS/START user's guide version 8.2. SAS Institute, Cary, N.C.
Soil Survey Staff. 1996. Soil taxonomy. 7th ed. USDA Agric. Handb. 436.

Thompson, R. 1985. The nitrate issue: a review. Soil Use Manage. 1: $102-103$.

Timmer, V.R. 1997. Exponential nutrient loading: a new fertilization technique to improve seedling outplanting performance on competitive sites. New For. 13: 279-299.

Timmer, V.R., and Aidelbaum, A.S. 1996. Manual for exponential nutrient loading of seedlings to improve outplanting performance on competitive forest sites.Natural Resources Canada, Canadian Forest Service, Great Lakes Forestry Centre, Sault Ste. Marie, Ont. NODA/NFP Tech. Rep. TR-25.

Timmer, V.R., and Parton, W.J. 1984. Optimum nutrient levels in container growing medium determined by a saturated aqueous extract. Commun. Soil Sci. Plant Anal. 15: 607-618.

Trofymow, J.A., and van den Driessche, R. 1991. Mycorrhizas. In Mineral nutrition of conifer seedlings. Edited by R. van den Driessche. CRC Press LLC, Boca Raton, Fla. pp. 183-227.

Wenny, D.L., and Dumroese, R.K. 1994. Nursery production: growing western white pine and western redcedar in greenhouses. In Symposium Proceedings, Interior Cedar-Hemlock-White Pine Forests: Ecology and Management, Spokane, Wash., 2-4 March 1993. Edited by D.M. Baumgartner, J.E. Lotan, and J.R. Tonn. Washington State University Cooperative Extension, Pullman, Wash. pp. 261-266.

White, J.W., and Marstalerz, J.W. 1966. Soil moisture as related to container capacity. Am. Soc. Hort. Sci. 89: 758-765.

World Health Organization. 2004. Chemical aspects. In Guidelines for drinking-water quality. Vol. 1. Recommendations. 3rd ed. World Health Organization, Geneva. 